of Management

Volume 1, Nomor 2, Juli - Desember 2020

P-ISSN: 2722-4937, E-ISSN: 2722-4961

Website: http: pasca-umi.ac.id/index.php/jms

This work is licensed under a Creative Commons Attribution 4.0 International License.

\title{
Pengaruh Pendidikan, Pelatihan, dan Mutasi Terhadap Kinerja Pegawai Negeri Sipil Pada Sekretariat Daerah Kabupaten Sinjai
}

\author{
A.PM. Yusmanto ${ }^{1 *}$, Nurwanah ${ }^{2}$ \\ ${ }^{1}$ Balai Besar KarantinaMakassar.Email: andi.yusmanto@ymail.com \\ 2 Fakultas Ekonomi dan Bisnis, Universitas Muslim Indonesia, Makassar. \\ Email Korespondensi: andi.yusmanto@ymail.com
}

\begin{abstract}
Abstrak
The results of this study indicate that all the variables, namely : Education, Training, And Movements , have a positive and significant effect simultaneously on the performance of Civil Servants On the Regional Secretariat of Sinjai . Being partially found that training factors that have a significant influence most dominant performance of Civil Servants On Regional Secretariat Sinjai.
\end{abstract}

Kata Kunci: Education, training , Mutation and performance

\section{Pendahuluan}

Sekretariat Daerah Kabupaten Sinjai merupakan salah satu instansi daerah sebagai unsur pelaksana pemerintah daerah yang dipimpin oleh seorang Sekretaris Daerah yang berada dibawah dan bertanggungjawab kepada Bupati mempunyai tugas pokok dan fungsi melaksanakan kewenangan desentralisasi, dekonsentrasi dan tugas pembatuan serta kewenangan yang tidak atau tidak belum dapat dilaksanakan oleh kabupaten/kota sesuai dengan peraturan perundang-undangan.

Kunci keberhasilan pemerintah terletak pada manajemen sumber daya manusia sebagai lokomotif penggerak keberhasilan pelaksanaan tugas pokok dan fungsinya . Pegawai sebagai sumber daya manusia dituntut untuk mampu menghadapi dinamika kerja yang semakin kompetitif. Dinamika organisasi pemerintahan seringkali mendapat sorotan dikarenakan tidak ada bukti konkrit dari keinginan baik (goodwill) untuk mewujudkan pemerintahan yang baik. Suatu kemustahilan untuk mewujudkan pemerintahan yang baik tanpa melakukan pembenahan sumber daya manusia terlebih dahulu. Sumber daya manusia merupakan unsur penting bagi kemajuan organisasi pemerintah. Instansi pemerintah sebagai organisasi non profit selalu membenahi diri untuk mengembangkan sumber daya manusia untuk meningkatkan kinerja pegawai dalam menjalankan tugas pokok dan fungsinya. Berikut ditunjukkan data persentase kinerja berdasarkan hasil tim evaluasi menunjukkan bahwa dari 101 orang pada tahun 2014 meningkat menjadi 111 orang pegawai pada tahun 2015 pada Sekretariat Daerah Kabupaten Sinjai. Persentase kinerja pegawai mengalami penurunan dalam lima tahun terakhir. Penurunan tersebut terlihat persentase kinerja berdasarkan penilaian tupoksi yang dilakukan oleh pimpinan pada tahun 2011 realisasi yang dicapai sebesar 92.1\% mengalami penurunan sampai $81.7 \%$ pada tahun 2015 yang tidak mencapai target $>90 \%$. Lebih jelasnya ditunjukkan pada Tabel 1 di bawah ini: 
Tabel 1. Data Rata-rata Pencapaian Kinerja Pegawai Sekretariat Daerah Kabupaten Sinjai Tahun $2017-2018$

\begin{tabular}{|c|c|c|}
\hline \multirow{2}{*}{ Tahun } & \% Kinerja dari Penilaian Penyelesaian Aktivitas Kerja \\
\cline { 2 - 3 } & Realisasi & Target \\
\hline 2014 & 92.1 & $90-100$ \\
\hline 2015 & 90.5 & $90-100$ \\
\hline 2016 & 89.2 & $90-100$ \\
\hline 2017 & 85.4 & $90-100$ \\
\hline 2018 & 81.7 & $90-100$ \\
\hline
\end{tabular}

Sumber: Sekretariat Daerah Kabupaten Sinjai, 2019

Data di atas menunjukkan bahwa persentase penurunan kinerja pegawai menjadi kesenjangan bagi Sekretariat Daerah Kabupaten Sinjai. Berikut ditunjukkan teori yang menjadi pertimbangan untuk memperbaiki pengembangan dan kinerja pegawai. Untuk teori pengembangan SDM, perlu diterapkan teori orientasi kerja (Heikkilä et al., 2017) menyatakan bahwa pengembangan sumber daya manusia dibenahi untuk peningkatan kinerja individu dan organisasi. Unsur pengembangan dalam organisasi yang seharusnya diperhatikan tingkat pendidikan, pelatihan dan mutasi yang diterapkan. Teori orientasi kerja ini diperlukan untuk peningkatan kinerja pegawai. Memahami pentingnya pengembangan dan pencapaian kinerja organisasi, ada beberapa peneliti sebelumnya yang mengamati hubungan tersebut antara lain (Mappamiring et al., 2020); (Akob et al., 2020); (Haerani et al., 2020); (Indahingwati et al., 2019); (Arfah \& Aditya, 2019) yang mengamati variabel yang sama, namun memiliki perbedaan dalam penentuan indikator yang digunakan sesuai teori yang menda sari cocok dalam penerapan fenomena yang melihat hubungan antara pengembangan SDM terhadap pencapaian kinerja, yang berpengaruh positif atau negatif dan signifikan atau tidak signifikan terhadap kinerja.

Pengembangan sumber daya manusia sebagai nachoda dalam menjalankan bahtera pemerintahan atau sebagai organisasi yang berjalan di atas landasan tujuan yang mengantar tercapainya kondisi pegawai pemerintahan yang bersih dan berwibawa. Tentunya pengembangan sumber daya manusia tidak terlepas peranan organisasi pemerintah yang menjadi wadah dalam memainkan peran sumber daya manusia yang menjadi investasi organisasi Sekretariat Daerah Kabupaten Sinjai. Peran pengembangan sumber daya manusia menekankan bahwa individuindividu dalam suatu organisasi adalah sumberdaya yang penting dan investasi bagi organisasi. Sumber daya manusia memainkan peranan strategis, berfokus pada berbagai masalah dan implikasi sumber daya manusia jangka panjang. Ilustrasi pengembangan sumber daya manusia, dalam suatu organisasi diharapkan mampu mengatasi masalah dan kekurangan yang ada saat ini, dan memberikan langkah-langkah pengembangan yang harus dilakukan dalam berbagai kebutuhan sumber daya manusia, yang sesuai dengan orientasi kerja.

Pengembangan sumber daya manusia yang perlu diperbaiki tanpa mengabaikan unsur-unsur lain yaitu pendidikan pegawai yang perlu ditingkatkan, mengingat dalam melaksanakan tugasnya diperlukan adanya pemahaman dan pengetahuan yang cukup dalam menjalankan aktivitas sosial kebudayaan dan pariwisata, dalam memberikan penyuluhan dan pencerahan kepada masyarakat, tentu dibutuhkan pegawai yang memiliki tingkat pendidikan yang sesuai dengan latar belakang, jenjang dan disiplin ilmu, sehingga pegawai perlu diberikan peluang pengembangan sumber daya manusia melalui peluang ikut tugas belajar, izin belajar dan inisiatif melanjutkan pendidikan yang lebih tinggi. Perubahan yang cukup substansial pada Sekretariat Daerah Kabupaten Sinjai, saat ini perlu pengembangan SDM yang efektif. Pengembangan ini memberi respon dalam peningkatan pemenuhan kebutuhan staf organisasi yang berkualitas sesuai dengan visi, misi, tujuan dan strategi organisasi Sekretariat Daerah Kabupaten Sinjai. Efektivitas pengembangan SDM diperlukan agar kontribusi pencapaian tujuan mengalami peningkatan.

Visi Sekretariat Daerah Kabupaten Sinjai adalah "Terwujudnya Sinjai Bersatu yang sejahtera, unggul dalam kualitas hidup, terdepan dalam pelayanan publik. Untuk mewujudkan visi tersebut, maka salah satu misi yang dilksanakan adalah meningkatkan sumber daya manusia dalam berbagai aspek kehidupan. Salah satu indikasi dari rendahnya efektivitas pengembangan SDM, dikarenakan bahwa pendidikan pegawai masih rendah, pelatihan kerja yang diikuti juga masih jarang dilakukan. Selain itu, mutasi yang dilakukan dalam suatu organisasi belum bersifat pemeliharaan dan upaya 
memberikan prestasi kepada pegawai. Seperti halnya di Sekretariat daerah Kabupaten Sinjai. Memahami indikasi dari penyebab kurang efektifnya pengembangan sumber daya manusia dikarenakan pendidikan yang masih rendah, pelatihan yang masih kurang cakap dan frekuensi mutasi yang sering dilakukan merupakan bagian dari pengembangan sumber daya manusia yang perlu dilihat secara utuh.

Mengembang tugas pokok dan fungsi yang diwewenangkan pada pegawai, terlihat pegawai masih perlu ditingkatkan keterampilannya dalam menghadapi dinamika kerja keseharian melalui pelatihan, akibat kurang terampil masyarakat yang dilayani kecewa atas pelayanan yang diberikan, terlihat pegawai dalam melayani kurang cakap, terkadang membutuhkan waktu yang lama dalam proses layanan, tidak terlatih dalam memberikan pelayanan yang handal, tidak menunjukkan kemampuan profesionalisme dalam melayani dan tidak menunjukkan keahlian melayani dengan baik, karenanya pegawai perlu ditingkatkan pengembangan sumber daya manusia melalui pengikutsertaan dalam berbagai pelatihan untuk menambah keterampilan dalam menjalankan tugas pokok dan fungsinya di Sekretariat Daerah Kabupaten Sinjai.

Disisi lain pegawai di dalam menjalankan tugas pokok dan fungsinya, diperhadapkan oleh adanya kondisi yang memungkinkan pegawai dapat berprestasi, mendapatkan pemeliharaan kerja dan pengenaan hukuman akibat kesalahan atau pelanggaran, sehingga diperlukan adanya pengembangan SDM melalui pemberian mutasi. Pemberian mutasi tersebut berupa mutasi promosi jabatan, penghargaan, kompetensi dan pengenaan sanksi. Uraian di atas merupakan gambaran tentang pentingnya pendidikan, pelatihan dan mutasi untuk diterapkan dalam suatu organisasi sebagai upaya untuk meningkatkan kualitas sumber daya manusia dalam menjalankan aktivitas organisasi untuk mencapai tujuannya

Tabel 2: Rumusan dan Tujuan Penelitian

\begin{tabular}{|c|c|}
\hline Rumusan Masalah & Tujuan Penelitian \\
\hline $\begin{array}{l}\text { 1. } 1 . \quad \text { Apakah pendidikan berpengaruh } \\
\text { terhadap kinerja pegawai negeri sipil pada } \\
\text { Sekretariat Daerah Kabupaten Sinjai? }\end{array}$ & 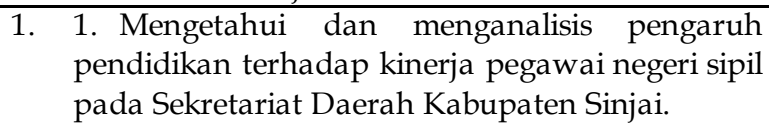 \\
\hline $\begin{array}{l}\text { 2. 2. Apakah pelatihan berpengaruh terhadap } \\
\text { kinerja pegawai negeri sipil pada Sekretariat } \\
\text { Daerah Kabupaten Sinjai? }\end{array}$ & $\begin{array}{l}\text { 2. Mengetahui dan menganalisis pengaruh } \\
\text { pelatihan terhadap kinerja pegawai negeri sipil } \\
\text { pada Sekretariat Daerah Kabupaten Sinjai. }\end{array}$ \\
\hline $\begin{array}{l}\text { 3. Apakah mutasi berpengaruh terhadap kinerja } \\
\text { pegawai negeri sipil pada Sekretariat Daerah } \\
\text { Kabupaten Sinjai? }\end{array}$ & $\begin{array}{l}\text { 3. Mengetahui dan menganalisis pengaruh } \\
\text { mutasi terhadap kinerja pegawai negeri sipil } \\
\text { pada Sekretariat Daerah Kabupaten Sinjai. }\end{array}$ \\
\hline $\begin{array}{l}\text { 4. 4. Variabel mana yang berpengaruh dominan } \\
\text { terhadap kinerja pegawai negeri sipil pada } \\
\text { Sekretariat Daerah Kabupaten Sinjai? }\end{array}$ & $\begin{array}{l}\text { 4. Mengetahui dan menganalisis variabel yang } \\
\text { dominan berpengaruh terhadap kinerja pegawai } \\
\text { negeri sipil pada Sekretariat Daerah Kabupaten } \\
\text { Sinjai. }\end{array}$ \\
\hline
\end{tabular}

Hasil penelitian ini diharapkan akan memperkaya pengembangan teori-teori ilmu manajemen sumber daya manusia dan menjadi sumbangan pemikiran bagi penelitian lainnya yang ingin meneliti lebih jauh dan mendalam mengenai pengembangan sumber daya manusia terhadap kinerja pegawai, khususnya hal-hal yang belum terungkap dalam penelitian ini. Sebagai bahan masukan bagi Sekretariat Daerah Kabupaten Sinjai dalam menerapkan pengembangan sumber daya manusia yang memberikan pengaruh terhadap kinerja pegawai.

Konsep ini yang mengantar pemikiran peneliti dalam melihat berbagai konsep mengenai organisasi pemerintah yang berkaitan dengan pengembangan sumber daya manusia sebagai kebijakan Sekretariat Daerah Kabupaten Sinjai untuk melakukan perubahan melalui peningkatan pendidikan, pelatihan dan mutasi pegawai dalam suatu organisasi kerja. Berdasarkan pengalaman empiris dan beberapa teori yang menyatakan bahwa pendidikan, pelatihan dan mutasi kerja sangat penting dalam pengembangan sumber daya manusia. Berdasarkan uraian gambaran mengenai alur pemikiran dalam penelitian ini, maka kerangka konsep adalah sebagai berikut: 


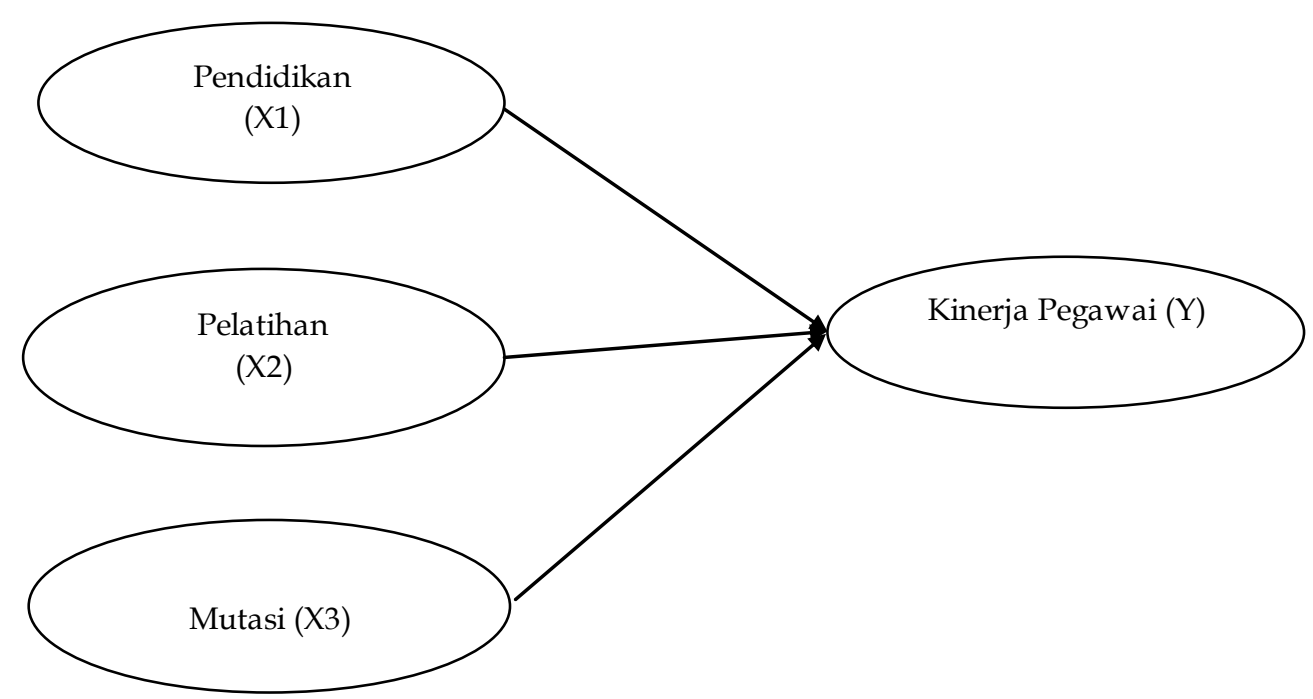

Gambar 1: Kerangka Konseptual

Berdasarkan uraian di atas, maka dirumuskan permasalahan dalam penelitian ini adalah:

1. Pendidikan berpengaruh positif dan signifikan terhadap kinerja pegawai negeri sipil pada Sekretariat Daerah Kabupaten Sinjai.

2. Pelatihan berpengaruh positif dan signifikan terhadap kinerja pegawai negeri sipil pada Sekretariat Daerah Kabupaten Sinjai.

3. Mutasi berpengaruh positif dan signifikan terhadap kinerja pegawai negeri sipil pada Sekretariat Daerah Kabupaten Sinjai.

4. Pendidikan yang dominan berpengaruh terhadap kinerja pegawai pada Sekretariat Daerah Kabupaten Sinjai.

\section{Tinjauan Pustaka}

(Sahir et al., 2020) mengemukakan bahwa manajemen sumber daya manusia adalah pendayagunaan, pengembangan, penilaian, pemberian balas jasa, dan pengelolaan individu anggota organisasi atau kelompok karyawan. Selanjutnya pengertian sumber daya manusia menurut (Hariandja, 2005) adalah perencanaan, pengorganisasian, pengarahan, dan pengawasan kegiatankegiatan pengadaan, pengembangan, pemberian kompensasi, pengintegrasian, pemeliharaan, dan pelepasan sumber daya manusia agar tercapai tujuan organisasi dan masyarakat. (Asrar-ul-Haq \& Kuchinke, 2016) mengemukakan bahwa manajemen sumber daya manusia adalah penerapan manajemen berdasarkan fungsinya untuk memperoleh sumber daya manusia yang terbaik bagi bisnis yang kita jalankan dan bagaimana sumber daya manusia yang terbaik tersebut dapat dipelihara dan tetap bekerja bersama kita dengan kualitas pekerjaan yang senantiasa konstan ataupun bertambah.

\subsection{Kinerja dan Penilaian Kinerja}

Kinerja adalah hasil pelaksanaan suatu pekerjaan, baik bersifat fisik/material maupun non fisik/non material yang dalam melaksanakan tugasnya berdasarkan deskripsi pekerjaan perlu dinilai hasilnya setelah tenggang waktu tertentu (Alfes et al., 2013). Hasibuan (2011) menyatakan bahwa kinerja adalah suatu hasil kerja yag dicapai seseorang dalam melaksanakan tugas-tugas yang dibebankan kepadanya yang didasarkan atas kecakapan, pengalaman, dan kesungguhan serta waktu. Menurut Nawawi (2005), pada hakekatnya penilaian kinerja karyawan yang merupakan kegiatan manajemen SDM adalah suatu proses pengamatan (observasi) terhadap pelaksanaan pekerjaan oleh seorang pekerja yang memiliki hak-hak asasi yang dilindungi. Menurut Hasibuan (2011) dan (Afsar et al., 2015) penilaian kinerja adalah menilai rasio hasil kerja nyata dengan standar kualitas maupun kuantitas yang dihasilkan setiap karyawan, menetapkan kebijaksanaan mengenai promosi atau balas jasanya. 
Istijanto (2006) menjabarkan bahwa indikator/tolak ukur/kriteria bawahan dalam melaksanakan pekerjaan terdiri atas beberapa aspek yaitu kualitas kerja, tanggung jawab terhadap pekerjaan, kerja sama dengan rekan kerja, orientasi terhadap pelanggan dan inisiatif karyawan. Pada giliran berikutnya, hasil dari penilaian/pengukuran kinerja karyawan dapat dijadikan informasi yang berharga bagi para manajer, misalnya dapat melihat apakah pekerja mengerjakan tugas yang sudah menjadi tanggung jawabnya, memberikan gambaran tentang kekurangan dan kelebihan pekerja dalam melaksanakan tugasnya, mengetahui keefektifan dan keefisienan kontribusi pekerja ter hadap organisasi, dapat dikaitkan dengan pengambilan keputusan dan kebijakan manajer, dan dapat dipergunakan untuk berbagai tujuan organisasi/ perusahaan seperti pengembangan karir (promosi atau pemindahan), suksesi dan kaderisasi, penyusunan program pengembangan dan pelatihan karyawan, penetapan gaji/upah dan kompensasi tidak langsung, review strategi bisnis dan lain-lain (Shahzad et al., 2016).

\subsection{Faktor Pendidikan, Pelatihan dan Mutasi}

Pendidikan adalah suatu upaya sadar dan terencana untuk dapat memberikan suatu wahana dan wawasan tentang pengetahuan kerja dan cara mengerjakan pekerjaan sesuai orientasi kemajuan pekerjaan. Akan berbeda pegawai yang memiliki pendidikan yang tinggi dengan pegawai yang tidak memiliki pendidikan tinggi. Sahir et al (2020) mengemukakan bahwa pendidikan adalah concerned with increasing general knowledge and understanding our total environment. Pendidikan adalah berhubungan dengan peningkatan pengetahuan umum dan pemahaman atas lingkungan kita secara menyeluruh. Huang et al (2020) menyatakan bahwa pendidikan mempunyai pengaruh langsung yang dengan cepat merubah cara berpikir seseorang dengan penambahan ilmu pengetahuan seseorang dapat bersikap simpatik dan berpandangan luas. Proses tersebut di dapat melalui berbagai lembaga pendidikan baik negeri maupun swasta, keluarga dan masyarakat. Pendidikan pegawai disini adalah kegiatan pengembangan sumber daya manusia, untuk meningkatkan total dari pegawai diluar kemampuan dibidang pekerjaan atau jabatan yang dipegang saat ini. Hasbullah (2005 : 53) mengemukakan ditinjau dari sudut tingkatan bahwa jenjang pendidikan formal terdiri atas pendidikan dasar, pendidikan menengah, pendidikan tinggi. Jenjang pendidikan formal untuk pendidikan tinggi terdiri dari Akademi, Institut, Sekolah Tinggi, dan Universitas, yang didalamnya sudah termasuk jalur pendidikan melalui Diploma Tiga, Strata Satu, dan Strata Dua. Menurut (Suazo et al., 2009) pelatihan merupakan salah satu kunci manajemen sumber daya manusia dan tanggungjawab yang tidak dapat dilaksanakan secara sembarangan. Artinya efektifitas pelatihan dapat terjamin, perlu penanganan yang serius baik yang menyangkut sarana maupun prasarananya. $(\mathrm{Lu}, 2011)$ mengemukakan pelatihan menurut sifatnya dapat dibedakan menjadi beberapa jenis yaitu pelatihan umum, pelatihan keahlian dan pelatihan kejuruan. pelatihan umum dilaksanakan di dalam dan diluar suatu organisasi, baik yang diselenggarakan oleh pemerintah maupun swasta dengan tujuan mempersiapkan dan mengusahakan para peserta pendidikan memperoleh pengetahuan dan keterampilan umum. pelatihan keahlian merupakan pengembangan pengetahuan dan keterampilan yang disyaratkan untuk melaksanakan suatu pekerjaan, termasuk pendidikan dan pelatihan ketatalaksanaan. sedangkan pelatihan kejuruan adalah peningkatan pengetahuan dan keterampilan yang disyaratkan untuk melaksanakan suatu pekerjaan yang bertaraf lebih rendah daripada pelatihan keahlian. (Martínez-Jurado et al., 2014) menyatakan bahwa pelatihan bertujuan untuk membantu mencapai tujuan organisasi dengan memberikan kesempatan kepada individu sumber daya manusia pada semua tingkatan organisasi untuk memperoleh pengetahuan, keahlian, kecakapan, keterampilan dan sikap yang diperlukan. Mutasi pegawai merupakan proses kegiatan yang dapat mengembangkan posisi atau status seorang pegawai dalam lingkup organisasi. Suatu mutasi pegawai yang paling banyak terjadi adalah atas keinginan organisasi. Hal ini dilakukan dengan pertimbanganpertimbangan antara lain: usaha organisasi/perusahaan untuk menghilangkan kejenuhan karyawan, kemampuan yang dimiliki karyawan kurang sesuai dengan kualifikasi pendidikan atau pelatihan, lingkungan pekerjaan yang kurang mendukung pelaksanaan pekerjaan, sistem dan prosedur kerja yang berubah, serta sebagai sanksi bagi karyawan/pegawai yang bersangkutan. (Kusuma et al., 2020) mengatakan bahwa mutasi dapat pula disebabkan atas permintaan karyawan sendiri dengan alasan pribadi dan keluarga, kesehatan, lingkungan kerja yang cocok, hubungan kerja yang kurang harmonis, beban tugas yang dirasa terlalu berat, serta tingkat pendidikan yang berubah. 


\section{Metode Penelitian}

Penelitian ini menggunakan dua pendekatan, yaitu pendekatan deskriptif (descriptive research) dan pendekatan eksplanatori (eksplanatori research). Penelitian ini menggunakan pendekatan deskriptif, karena peneliti berusaha untuk menjelaskan hasil penelitian dengan menggunakan table,gambar dan grafik mengenai data yang telah diolah. Sedangkan pendekatan eksplanatori (independen variables) terhadap variable dependen (dependend variables). Variable independen (independen variables) dalam penelitian ini terdiri dari variabel Pendidikan (X1),Pelatihan (X2) dan mutasi (X2). Sedangkan variabel dependen (dependend variables) adalah kinerja pegawai.

Penelitian ini dilakukan di Sekretariat Daerah Kabupaten Sinjai selama 3 bulan dari bulan Maret sampai Juni 2019. Jenis data yang digunakan dalam penelitian ini adalah data kuantitatif yaitu penelitian yang memberikan penjelasan dari hasil penelitian berupa interpretasi hasil olah data yang dijelaskan secara induktif yaitu berfokus pada pengaruh dari variabel bebas terhadap variabel terikat. Sumber data berupa data primer dan data sekunder. Teknik pengumpulan data dimaksudkan untuk memperoleh data yang relevan dan akurat dengan masalah yang dibahas sehingga metode pengumpulan data yang digunakan dalam penelitian ini adalah observasi, wawancara, kuesioner, dan dokumentasi. Populasi dalam penelitian ini adalah keseluruhan pegawai Sekretariat Daerah Kabupaten Sinjai yang berjumlah 111 orang karyawan (data dari pihak Sekretariat Daerah Kabupaten Sinjai). Penentuan sampel yang akan dianalisa diambil dari populasi keseluruhan. Karena populasi keseluruhan berjumlah cukup besar, sehingga tidak mungkin untuk meneliti keseluruhan maka diambil sampel untuk dianalisa, berdasarkan rumus Slovin (Umar, 2003: 108) adalah sebagai berikut:

$$
\begin{aligned}
& \mathrm{N}=\frac{\mathrm{N}}{1+\mathrm{Ne}^{2}} \\
& 111 \quad 111 \\
& =\quad \text { - }=0 \\
& =52.60 \text { dibulatkan }=53 \text { responden }
\end{aligned}
$$

Keterangan:

$\mathrm{n}=$ Ukuran Sampel

$\mathrm{N}=$ Ukuran populasi

$\mathrm{e}=$ Persen kelonggaran ketidakpastian karena kesalahan pengambilan sampel yang masih dapat ditolerir, maksimum sebesar $10 \%$.

Berdasarkan hasil perhitungan, jumlah sampel yang akan diambil dalam penelitian ini adalah sejumlah 52.60 yang dibulatkan menjadi 53orang. Sampel ditarik dengan menggunakan metode proportional sampling. Hal ini untuk menghindari terjadinya bias akibat pengulangan dalam pengambilan data. Secara lebih jelas dapat dilihat pada tabel 3 berikut:

Tabel 3 : Populasi dan Sampel

\begin{tabular}{|r|l|c|r|r|}
\hline No & Responden & Jml ( Org) & Persentase (\%) & Jumlah Sampel \\
\hline 1. & Sekertaris & 1 & $1 / 111$ X53 & $0,48(1)$ \\
2 & Asisten. & 3 & $3 / 111$ X53 & $1,43(1)$ \\
3 & Staf Ahli & 3 & $3 / 111$ X53 & $1,43(1)$ \\
4 & Kepala bagian & 10 & $10 / 111$ X53 & $4,77(5)$ \\
5 & Kasubag & 33 & $33 / 111$ X53 & $15,76(16)$ \\
6 & Staf & 61 & $61 / 111$ X53 & $29,12(29)$ \\
\hline & Jumlah & $\mathbf{1 1 1}$ & & $\mathbf{5 3}$ \\
\hline
\end{tabular}

Sumber: Sekretariat Daerah Kabupaten Sinjai.2019

Metode analisis data yang digunakan adalah analisis secara deskriptif yaitu menganalisa pengaruh pengembangan SDM terhadap kinerja pegawai pada Sekretariat Daerah Kabupaten Sinjai 
dan metode analisis regresi linier berganda untuk menganalisis pengaruh pengembangan SDM terhadap kinerja pegawai pada Sekretariat Daerah Kabupaten Sinjai dengan rumus:

Dimana:

$$
\mathrm{Y}=\mathrm{b} 0+\mathrm{b} 1 \mathrm{X} 1+\mathrm{b} 2 \mathrm{X} 2+\mathrm{b} 3 \mathrm{X} 3+\mathrm{ei}
$$

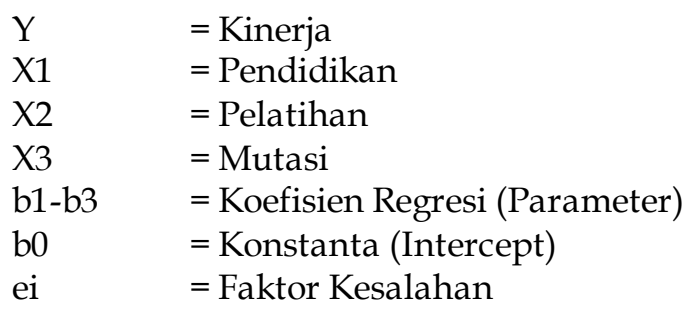

Selanjutnya untuk menentukan pengaruh dan tingkat signifikan $p=0.05$ atau $5 \%$ diuji dengan menggunakan uji-F dan uji-t melalui program komputer SPSS 20.0.

\subsection{Pengujian Hipotesis Secara Serempak}

Pengujian ini bertujuan untuk melihat pengaruh pendidikan, pelatihan dan mutasi terhadap kinerja pegawai pada Sekretariat Daerah Kabupaten Sinjai dengan melihat nilai F-hitungnya. Adapun hasil pengujian secara serempak, dapat dilihat pada tabel berikut ini.

\section{Tabel 4 : Pengujian Secara Simultan (Uji-F)}

\begin{tabular}{|c|c|c|c|c|c|c|}
\hline \multicolumn{2}{|c|}{ Model } & Sum of Squares & $\mathrm{df}$ & Mean Square & $\mathrm{F}$ & Sig. \\
\hline \multirow{3}{*}{1} & Regression & 10.975 & 3 & 3.658 & 213.862 & $.000^{\mathrm{a}}$ \\
\cline { 2 - 7 } & Residual & .838 & 49 & .017 & & \\
\cline { 2 - 7 } & Total & 11.813 & 52 & & & \\
\hline
\end{tabular}

Data pada tabel di atas menunjukkan bahwa nilai F-hitung yang diperoleh yaitu 213.862 sedangkan F-tabel pada selang kepercayaan 95\% atau tingkat kesalahan $(\alpha=0,05)$ akan diperoleh angka 2.78 Dengan demikian, nilai F-hitung $>$ F-tabel atau $213.862>2.78$ yang berarti, variabel bebas akan berpengaruh serempak dengan variabel dependent. Signifikansi tinggi karena 0,000 lebih kecil dari tingkat alpha sebesar 0,05. Hal ini dapat ditarik kesimpulan bahwa secara serempak variabel pendidikan, pelatihan dan mutasi berpengaruh signifikan dan positif terhadap kinerja Pegawai Sekretariat Daerah Kabupaten Sinjai.

\subsection{Pengujian Hipotesis Secara Parsial}

Pengujian Hipotesis secara parsial ini digunakan untuk melihat pengaruh dari variabel pendidikan, pelatihan dan mutasi terhadap kinerja pegawai pada Sekretariat Daerah Kabupaten Sinjai Hasil pengujiannya dapat dilihat dari nilai t-hitungnya. Adapun hasil pengujian secara parsial (thitung) maka dapat dilihat dari tabel 4.

Tabel 4 :Pengujian Secara Parsial (Uji-t)

\begin{tabular}{|c|c|c|c|c|c|c|}
\hline & \multirow{2}{*}{ Model } & \multicolumn{2}{|c|}{ Unstandardized Coefficients } & \multirow{2}{*}{$\begin{array}{l}\text { Standardized } \\
\text { Coefficients Beta }\end{array}$} & \multirow{2}{*}{$\mathrm{t}$} & \multirow{2}{*}{ Sig. } \\
\hline & & B & Std. Error & & & \\
\hline \multirow{4}{*}{1} & (Constant) & .068 & .159 & & .423 & .674 \\
\hline & Pendidikan X1 & .199 & .081 & .202 & 2.452 & .018 \\
\hline & Pelatihan X2 & .423 & .063 & .429 & 6.722 & .000 \\
\hline & Mutasi X3 & .371 & .085 & .399 & 4.351 & .000 \\
\hline
\end{tabular}


Berdasarkan pengujian secara parsial seperti pada tabel di atas menunjukkan bahwa pendidikan, pelatihan dan mutasi secara individu berpengaruh signifikan dan positif terhadap kinerja pegawai pada Sekretariat Daerah Kabupaten Sinjai.Hal ini dapat diketahui dari nilai t-hitung yang diperoleh lebih besar dari t-tabel atau t-hitung lebih kecil dari t-tabel. Hasil analisis juga menunjukkan dari ketiga variabel yang berpengaruh, ternyata variabel pelatihan mempunyai pengaruh dominan dalam meningkatkan kinerja Pegawai Sekretariat Daerah Kabupaten Sinjai, hal ini dapat dilihat dari nilai thitung pelatihan lebih besar dari nilai thitung dari pendidikan dari nilai thitungdan mutasi

Selanjutnya pada tabel 5, dapat diketahui bahwa hasil persamaan regresi linier berganda dari model penelitian ini adalah sebagai berikut :

$$
Y=0,068+0,199 X_{1}+0,423 X_{2}+0,371_{X 3}
$$

Berdasarkan persamaan regresi linier berganda tersebut diatas, maka dapat diinterpresentasikan sebagai berikut ini :

a. b0 = diperoleh dari nilai 0,068 yang menyatakan bahwa kinerja pegawai pada Sekretariat Daerah Kabupaten Sinjai cenderungmeningkat jika variable pendidikan (X1), pelatihan (X2), dan mutasi (X3) dalam posisi konstan.

b. $b 1=0,199$, mempunyai arti positif yang menunjukkan bahwa pendidikanberpengaruh positif dan signifikan terhadap kinerja pegawai pada Sekretariat Daerah Kabupaten Sinjai , koefisien b1 tersebut signifikan dengan nilai $p=0,018$ lebih kecil dari 0,05. Dapat dijelaskan bahwa apabila ada peningkatan variabel pendidikan dan variabel lainnya konstan, maka akan meningkatkan kinerja pegawai pada Sekretariat Daerah Kabupaten Sinjai .

c. b2 $=0,423$, memiliki tanda positif yang menunjukkan bahwa pelatihanberpengaruh positif terhadap kinerja pegawai pada Sekretariat Daerah Kabupaten Sinjai .Koefisian b2 tersebut signifikan karena nilai $\mathrm{p}=0,000$ dan lebih kecil dari 0,05. Hal tersebut dapat dijelaskan apabila terjadi peningkatan pelatihan dan variabel bebas lainnya konstan, maka terjadi peningkatan kinerja pegawai pada Sekretariat Daerah Kabupaten Sinjai .

d. b3 $=0,371$, memiliki tanda positif yang menunjukkan bahwa mutasi akan berpengaruh positif terhadap kinerja pegawai pada Sekretariat Daerah Kabupaten Sinjai .Koefisien b3 tersebut signifikan dikarenakan nilai $\mathrm{p}=0,000$ lebihkecil dari 0,05. Hal tersebut dapat dijelaskan bahwa apabila terjadi mutasi dan variabel bebas lain konstan, maka akan mempengaruhi peningkatan kinerja pegawai pada Sekretariat Daerah Kabupaten Sinjai .

Besarnya kontribusi yang diberikan dari variabel, pendidikan $\left(X_{1}\right)$, pelatihan $\left(X_{2}\right)$, dan mutasi $\left(\mathrm{X}_{3}\right)$ terhadap kinerja Pegawai Sekretariat Daerah Kabupaten Sinjaidapat dilihat dari koefisien determinasinya. Perolehan nilai determinasi $\left(R^{2}\right)$ dapat dilihat pada tabel dibawah ini.

Tabel 5 : Hasil pengujian Koefisien Determinasi $\left(\mathbf{R}^{2}\right)$

\begin{tabular}{|c|c|c|c|c|}
\hline Model & $\mathrm{R}$ & $\mathrm{R}$ Square & Adjusted R Square & Std. Error of the Estimate \\
\hline 1 & $.964^{\mathrm{a}}$ & .929 & .925 & .13079 \\
\hline \multicolumn{7}{|c|}{} \\
\hline
\end{tabular}

Berdasarkan nilai determinasi pada tabel 5 diatas, maka dapat dijelaskan bahwa besarnya koefisien determinasi $\left(\mathrm{R}^{2}\right)$ adalah 0,929 . Angka koefisien determinasi menyatakan bahwa variabel pendidikan $\left(\mathrm{X}_{1}\right)$, pelatihan $\left(\mathrm{X}_{2}\right)$, dan mutasi $\left(\mathrm{X}_{3}\right)$ hanya dapat menjelaskan atau memberikan kontribusi atas variasi perubahan kinerja pegawai sebesar $92,9 \%$. Sedangkan sisanya dipengaruhi oleh variabel-variabel lain yang tidak dilibatkan dalam penelitian ini.

\section{Pembahasan}

Berdasarkan tujuan penelitian ini yakni untuk mengetahui dan menganalisis pengaruh pendidikan $\left(X_{1}\right)$, pelatihan $\left(X_{2}\right)$, dan mutasi $\left(X_{3}\right)$ terhadap kinerja Pegawai Sekretariat Daerah Kabupaten Sinjai. Setelah dilakukan pengujian hipotesis penelitian ini, maka ketiga variabel bebas 
yakni: pendidikan $\left(X_{1}\right)$, pelatihan $\left(X_{2}\right)$, dan mutasi $\left(X_{3}\right)$ terhadap kinerja Pegawai Sekretariat Daerah Kabupaten Sinjai. Penelitian ini secara serentak atau bersama-sama ketiga variabel bebas terhadap variabel terikat yang menunjukkan pengaruh positif dan singnifikan yang dibuktikan dengan besarnya kontribusi (R2) = 0,929 atau 92,9\%. Artinya kinerja Pegawai Sekretariat Daerah Kabupaten Sinjai dapat diprediksikan bahwa untuk meningkatkan kinerja Pegawai perlu menggunakan ketiga variabel bebas tersebut. Sedang adanya sisa menunjukkan bahwa masih perlu mencari variabel yang belum dapat teridentifikasi dalam penelitian ini, sehingga bagi para peneliti selanjutnya harus menelusuri lebih mendalam sehingga ditemukan variabel yang dapat memperbesar pengaruh terhadap peningkatan kinerja Pegawai Sekretariat Daerah Kabupaten Sinjai tersebut. Oleh karena hasil analisis sesuai Tabel Anova terlampir, nilai probabilita $\mathrm{P}=0.000$ adalah lebih kecil dari 0.05 , maka secara serentak variabel $X_{1}, X_{2}$ dan $X_{3}$ berpengaruh nyata terhadap kinerja Pegawai $(Y)$. Dengan demikian, hipotesis pertama penelitian ini dapat diterima.

Selanjutnya, analisis parsial dengan SPSS 20 memperlihatkan hasil bahwa nilai Standardized beta yang terbesar ialah 0.429 , yaitu koofisien dari variabel $\mathrm{X}_{2}$ (pelatihan). Dengan demikian, variabel pelatihan $\left(X_{3}\right)$ yang paling besar pengaruhnya terhadap kinerja Pegawai $(Y)$. Sehubungan dengan itu, maka hipotesis kedua penelitian ini ditolak. Di samping, memperlihatkan temuan secara serentak atau simultan ketiga variable tersebut, maka secara parsial ketiga variable bebas juga perlu dibahas terhadap variabel terikatnya.

\subsection{Pengaruh pendidikan terhadap Kinerja Pegawai}

Pengetahuan adalah untuk melakukan suatu pekerjaan atau tugas yang dilandasi atas keterampilan dan pengetahuan serta didukung oleh sikap kerja yang dituntut oleh pekerjaan tersebut. Pengetahuan menunjukkan karakteristik yang dimiliki atau dibutuhkan oleh setiap individu untuk melakukan tugas dan tanggung jawab secara efektif dan meningkatkan standar kualit as profesional dalam pekerjaan. Hasil penelitian ini menunjukkan bahwa tingkat pendidikan yang dimiliki setiap Pegawai berpegaruh positif dan signifikan terhadap kinerja Pegawai. Jika setiap Pegawai mampu meningkatkan dan menempatkan dirinya bahwa mereka memiliki tingkat pendidikan yang dapat diterapkan untuk kepentingan organisasi dan untuk dirinya sendiri, maka peningkatan kinerja baik secara individu maupun organisasi juga dapat ditingkatkan. Dalam penelitian ini telah membuktikan pengetahuan yang dimiliki pegawai melalui pendidikan yang secara sistematis selalu disesuaikan kemampuan pendidikan, keterampilan dan bakat dalam berbagai tugas ternyata terbukti bahwa pendidikan berpengaruh positif dan signifikan terhadap kinerja pegawai. Di samping didukung oleh hasil penelitian melalui analisis deskriptif, juga dapat dibuktikan secara inferensial statistik regresi linear berganda yang menunjukkan pengaruh yang positif dan signifikansi yang relatif tinggi antara pendidikan dengan kinerja pegawai dengan sumbangan melalui $X 1=0,199$ atau $19,9 \%$ dan signifikansinya melalui thitung $=2,452$ dan probabilitasnya $=0,018<0,18$. Hal menunjukkan bahwa ternyata pendidikan yang dimiliki oleh pegawai relatif tinggi sehingga banyak membantu untuk meningkatkan kinerja pegawai. Dengan demikian, maka pendidikan memberikan petunjuk bahwa secara linear dengan semakin mampu untuk bekerja dengan baik.

Sejalan dengan temuan hasil penelitian yang telah dikemukakan di atas, maka penelitian ini dapat dikatakan bahwa ternyata Kantor Pada Kantor Sekretariat Daerah Kabupaten Sinjai sudah banyak melakukan penyesuaian antara kebutuhan sumberdaya manusia dengan kebutuhan kerja dalam rangka meningkatkan kinerja Pegawai dengan cara mendorong dan memotivasi Pegawai untuk meningkatkan kemampuan dan pengembangan diri melalui peningkatan pengetahuannya, mengikuti pelatihan dan bahkan mendorong untuk studi banding ke beberapa daerah atau negara yang sudah maju didukung dengan pendapat dari (Haerani et al., 2020) pelatihan adalah setiap usaha untuk memperbaiki performansi pekerja pada suatu pekerjaan tertentu yang sedang menjadi tanggungjawabnya atau suatu pekerjaan yang ada kaitannya dengan pekerjaannya.

\subsection{Pengaruh Pelatihan Terhadap Kinerja Pegawai}

Dalam penelitian ini telah membuktikan bahwa keikutsertaan pegawai dalam pelatihan ini dapat disesuaikan dengan teknis pelayanan kepada masyarakat ternyata terbukti bahwa pelatihan ini berpengaruh positif dan signifikan terhadap kinerja Pegawai, hal ini dapat didukung oleh hasil 
penelitian melalui analisis deskriptif yang memberi tanggapan bahwa sebanyak 50 Pegawai 100\% yang mengatakan bahwa pelatihan yang pernah diikuti oleh pegawai sesuai dengan tugas pokok dan fungsinya . Meskipun mereka lebih banyak memberikan penilaian bahwa pelatihan struktural dapat membantu memperlacar pekerjaan dalam rangka meningkatkan kinerja pegawai. Di samping, itu juga dibuktikan oleh hasil analisis statistik regresi liniear berganda yang ditunjukkan pengaruh yang positif dan signifikan melalui nilai thitung $=6,722$ dengan probablitas $=0,000<0,005$. Temuan hasil penelitian ini, dapat disimpulkan bahwa pengaruh pelatihan terhadap kinerja Pegawai. Dengan demikian, maka untuk mempercepat peningkatan Pegawai perlu diupayakan lebih banyak mengikuti dan meningkatkan keterampilannya melalui diklat baik dilakukan oleh lembaga departemen dalam negeri maupun di luar organisasi tersebut.

\subsection{Pengaruh Mutasi terhadap Kinerja Pegawai}

Hasil analisis penelitian ini membuktikan bahwa mutasi yang dimiliki oleh Pegawai berpengaruh signifikan terhadap kinerja Pegawai terutama pada jenjang pendidikan sederajat dengan SLTA dan hal ini dapat juga diperkuat oleh hasil penelitian melalui deskripsi tanggapan dari Pegawai yang diteliti memiliki kategori jenjang pendidikan Sarjana (S-1) dengan kategori tinggi. Sedang secara inferensial statistik juga menunjukkan pengaruh yang positif signifikansi yang relatif tinggi dengan menggunakan thitung $=4,351 \%$ dan signifikansi (probabilitas) $=0,000<0,005$. Dengan demikian, tingkat pendidikan Sarjana perlu dipertahankan sesuai ruang lingkup kerjanya, tetapi juga tetap mengupayakan peningkatan jenjang pendidikan yang lebih tinggi pada bidang-bidang tertentu yang memerlukan kemampuan wawasan dan analisis yang tinggi.

Sejalan dengan temuan hasil penelitian yang telah dikemukakan di atas, maka penelitian ini dapat dikatakan bahwa ternyata Kantor Pada Sekretariat Daerah Kabupaten Sinjai sudah banyak melakukan penyesuaian antara kebutuhan sumberdaya manusia dengan kebutuhan kerja dalam rangka meningkatkan kinerja Pegawai dengan cara mendorong dan memotivasi Pegawai untuk meningkatkan kemampuan dan pengembangan diri melalui peningkatan pengetahuannya, mengikuti pelatihan dan bahkan mendorong untuk studi banding ke beberapa daerah atau negara yang sudah maju. Dari hasil penelitian ini membuktikan bahwa secara bersama-sama ketiga variabel bebas tersebut berpengaruh secara siginifikan. Dari hasil pengujian hipotesis dapat disimpulkan bahwa:

1. Secara parsial pendidikan berpengaruh positif dan signifikan terhadap kinerja pegawai pada Sekretariat Daerah Kabupaten Sinjai. Hal ini disebabkan karena adanya peningkatan pendidikan pegawai sesuai dengan visi dan misi organisasi

2. Terdapat pengaruh positif dan signifikan secara parsial antara pelatihan dengan kinerja pegawai Sekretariat Daerah Kabupaten Sinjai

3. Terdapat pengaruh positif dan signifikan secara parsial antara mutasi dengan kinerja pegawai Sekretariat Daerah Kabupaten Sinjai

4. Faktor pelatihan paling dominan pengaruhnya terhadap kinerja pegawai Sekretariat Daerah Kabupaten Sinjai.

\section{Saran}

Sesuai hasil dan pembahasan serta kesimpulan penelitian yang telah dikemukakan sebelumnya, maka ada beberapa hal yang perlu disarankan, atau direkomendasikan kepada pimpinan manajemen pada Sekretariat Daerah Kabupaten Sinjai, yaitu:

1. Untuk meningkatkan dan memelihara kinerja pegawai terutama dalam hal pelayanan, maka manajemen perlu melakukan upaya penyempurnaan dan meningkatkan pengetahuan melalui pendidikan dan pelatihan.

2. Untuk lebih meningkatkan kinerja pegawai pada Sekretariat Daerah Kabupaten Sinjai maka masih perlu bersikap dan berperilaku yang ditunjukkan sebagai bagian dari dorongan atau dukungan yang berasal dari dalam dan luar diri pegawai.

3. Untuk pimpinan dalam mengambil kebijakan mutasi atau rotasi karyawan agar memberikan pengetahuan atau kenyamanan dalam penempatan agar karyawan tidak merasa ada pilih kasih pada penempatan kerja baru 
4. Untuk meningkatkan kinerja pegawai maka Sekretariat Daerah Kabupaten Sinjai maka saat dilakukan mutasi dilihat apa akan menciptakan keseimbangan antara tenaga kerja dengan jabatan yang ada dalam organisasi, sehingga dapat menjamin terjadinya kondisi ketenagakerjaan yang stabil, membuka kesempatan untuk mengembangkan karir dan untuk menambah pengetahuan dan pengalaman pegawainya.

\section{Daftar Pustaka}

Afsar, B., Badir, Y., \& Khan, M. M. (2015). Person-job fit, person-organization fit and innovative work behavior: The mediating role of innovation trust. The Journal of High Technology Management Research, 26(2), 105-116. https://doi.org/https://doi.org/10.1016/j.hitech.2015.09.001

Akob, M., Arianty, R., \& Putra, A. H. P. K. (2020). The mediating role of distribution Kahns engagement: An empirical evidence of salesforce in Indonesia. In Journal of Asian Finance, Economics and Business (Vol. 7, Issue 2, pp. 249-260). https:// doi.org/10.13106/jafeb.2020.vol7.no2.249

Alfes, K., Truss, C., Soane, E. C., Rees, C., \& Gatenby, M. (2013). The relationship between line manager behavior, perceived HRM practices, and individual performance: Examining the mediating role of engagement. Human Resource Management, 52(6), 839-859. https://doi.org/10.1002/hrm.21512

Arfah, A., \& Aditya, H. P. K. P. (2019). Analysis of Productivity and Distribution of Female Workers in FB's Industries. Journal of Distribution Science, 17(3), 31-39. https:// doi.org/10.15722/jds.17.03.201903.31

Asrar-ul-Haq, M., \& Kuchinke, K. P. (2016). Impact of leadership styles on employees' attitude towards their leader and performance: Empirical evidence from Pakistani banks. Future Business Journal, 2(1), 54-64. https://doi.org/10.1016/j.fbj.2016.05.002

Haerani, S., Sumardi, Hakim, W., Hartini, \& Putra, A. H. P. K. (2020). Structural Model of Developing Human Resources Performance: Empirical Study of Indonesia States Owned Enterprises. The Journal of Asian Finance, Economics and Business, 7(3), 211-221.

Hariandja, M. T. E. (2005). Manajemen Sumber Daya Manusia, PT. Grasindo, Jakarta.

Hasibuan, M. S. P. (2011). Manajemen Sumber Daya Manusia. Edisi Revisi Jakarta: Bumi Aksara. https://doi.org/10.1017/CBO9781107415324.004

Heikkilä, J.-P., Rentto, O., \& Feng, Y. (2017). Aiming for Strategic e-HRM: Motives and Consequences of e-HRM Implementation in an MNC. Electronic HRM in the Smart Era, 173-199. https://doi.org/10.1108/978-178714-315-920161007

Huang, C.-C., Jin, H., Zhang, J., Zheng, Q., Chen, Y., Cheung, S., \& Liu, C. (2020). The Effects of an Innovative ECommerce Poverty Alleviation Platform on Chinese Rural Laborer Skills Development and Family WellBeing. Children and Youth Services Review, 105189. https://doi.org/https://doi.org/10.1016/j.childyouth.2020.105189

Indahingwati, A., Launtu, A., Tamsah, H., Firman, A., Putra, A. H. P. K., \& Aswari, A. (2019). How Digital Technology Driven Millennial Consumer Behaviour in Indonesia. Journal of Distribution Science, 17(8), 25-34.

Kusuma, A. H. P., Sudirman, A., Purnomo, A., Aisyah, S., Sahir, S. H., Rumondang, A., Salmiah, S., Halim, F., Wirapraja, A., \& Napitupulu, D. (2020). Brand Management: Esensi, Posisi dan Strategi. Yayasan Kita Menulis.

$\mathrm{Lu}, \mathrm{J}$. (2011). Evaluation of enterprise human resources comprehensive abilities based on managerial psychology. Procedia Engineering, 16, 564-571. https:// doi.org/10.1016/j.proeng.2011.08.1125

Mappamiring, M., Akob, M., \& Putra, A. H. P. K. (2020). What Millennial Workers Want? Turnover or Intention to Stay in Company. The Journal of Asian Finance, Economics and Business, 7(5), 237-248.

Martínez-Jurado, P. J., Moyano-Fuentes, J., \& Jerez-Gómez, P. (2014). Human resource management in Lean Production adoption and implementation processes: Success factors in the aeronautics industry. BRQ Business Research Quarterly, 17(1), 47-68. https://doi.org/10.1016/j.cede.2013.06.004

Sahir, S. H., Hasibuan, A., Aisyah, S., Sudirman, A., Kusuma, A. H. P., Salmiah, S., Afriany, J., \& Simarmata, J. (2020). Gagasan Manajemen. Yayasan Kita Menulis.

Shahzad, K., Bajwa, S. U., Ansted, R. B., Mamoon, D., \& Khaliq-ur-Rehman. (2016). Evaluating human resource management capacity for effective implementation of advanced metering infrastructure by electricity distribution companies in Pakistan. Utilities Policy, 41,107-117. https://doi.org/10.1016/j.jup.2016.06.011

Suazo, M. M., Martínez, P. G., \& Sandoval, R. (2009). Creating psychological and legal contracts through human resource practices: A signaling theory perspective. Human Resource Management Review, 19(2), 154-166. https://doi.org/10.1016/j.hrmr.2008.11.002 